\title{
The Effects of Ether Anesthesia for Surface-Induced Hypothermia on Cardiopulmonary Function in the Dog
}

\author{
Isamu KANEMOTO ${ }^{1,2)}$, Tomonari MASUMOTO ${ }^{1)}$, Hiromi YOKOYAMA ${ }^{1}$, \\ Mituhiro NODA ${ }^{1)}$, Eiji SHIBATA ${ }^{3)}$, Gaku ICHIHARA ${ }^{4)}$, Katsuaki TAKASE ${ }^{5)}$ \\ and Shigeo OGASAWARA ${ }^{5)}$
}

\section{犬の低体温麻酔法の心肺機能に及ぼすエーテル麻酔深度の影響}

\author{
金本 勇 ${ }^{1,2)}$, 益本友成 ${ }^{1)}$, 横山宏美 ${ }^{1)}$, 野田光洋 ${ }^{1)}$, 柴田英治 ${ }^{3)}$, 市原 学 ${ }^{4)}$, \\ 高瀬勝晤 ${ }^{5)}$, 小笠原成郎 ${ }^{5)}$
}

〔平成 15 年 4 月 16 日受付 /平成 15 年 8 月 9 日受理〕

\author{
SUMMARY
}

\begin{abstract}
The effects of the depth of ether anesthesia for surface-induced hypothermia on hemodynamics and blood gas were experimentally studied in the adult Beagle dogs. The dogs were classified into 3 groups according to the depth of ether anesthesia; group I (middle), group II (deep), and group III (light). Severe arrhythmia was found in groups II and III, and 6 dogs $(66.7 \%)$ of group II died of ventricular fibrillation or standstill. During hypothermia, hemodynamic changes of groups I and III were significantly milder than those of group II. Aortic mean pressure of group I was maintained higher than that of group III, and the difference was especially significant at the esophageal temperature of $20^{\circ} \mathrm{C}(p<0.01)$. From these results, the ether anesthesia in group I seemed to be superior to that of other groups. Under this level of ether anesthesia, the mean blood ether concentration was $153 \mathrm{mg} / \mathrm{d} l$ at the esophageal temperature of $20^{\circ} \mathrm{C}$. Moreover, because a good correlation was noted between blood $\mathrm{pH}$ or $\mathrm{BE}$ and blood ether concentration, it seemed that they were better indicators of the depth of ether anesthesia.
\end{abstract}

Key words : blood ether concentration (エーテル血中濃度), blood gas (血液ガス), ether anesthesia (エーテル麻酔), hemodynamics (血行動態), surface-induced hypothermia（表面冷却低体温麻 酔)

\section{INTRODUCTION}

In human heart surgeries, the surfaceinduced hypothermia was replaced by the cardiopulmonary bypass system. In canine heart surgeries, however, the surface-induced hypothermia is still useful because it is well suited to small-sized dogs, inexpensive, and simple to perform. In the past, surface-induced hypothermia techniques using various kinds of anesthetic agents, such as thiopental sodium $^{23)}$, morphine ${ }^{8)}$, fentaniel ${ }^{14)}, \mathrm{NLA}^{1)}$, halothane $^{19)}$, azeotrope ${ }^{4)}$, isofluren ${ }^{15)}$, and others ${ }^{20)}$ were reported. They were almost 
always experimentally used, and were hardly applied in clinical trials due to unstable results. However, surface-induced hypothermia with ether anesthesia has been used in many clinical cases because of its wide safety in the anesthetic phase, stable hemodynamics and antiarrythmic effects ${ }^{6,} 7,9-13,18,22$.

In the majority of such studies, deeper ether anesthetic phase was used for surfaceinduced hypothermia, however the depth of ether anesthesia was decided empirically rather than the scientific background. Although there have been a few reports on the depth of ether anesthesia ${ }^{6,17,22)}$ through measuring blood ether concentrations, the measurement requires the complex procedures. Recently, the modern and simpler methods such as gas chromatography or infra-red analysis have become available ${ }^{2)}$, which may enable to assess the reliable blood ether concentration during the anesthesia.

The purpose of this study was to clarify the optimal anesthetic phase of ether anesthesia for hypothermia and blood ether concentrations from the aspect of cardiopulmonary functions.

\footnotetext{
${ }^{1)}$ Chayagasaka Animal Hospital, 1-1-5 Shinnishi, Chikusa-ku, Nagoya 464-0003,

${ }^{2)}$ Institute for Laboratory Animal Research, Nagoya University School of Medicine, Nagoya 466-0065, ${ }^{3)}$ Department of Medical Technology, Nagoya University School of Health Sciences, Nagoya 461-0047, ${ }^{4)}$ Department of Occupational and Enviromental Health, Nagoya University Graduate School of Medicine, Nagoya 466-0065,

${ }^{5)}$ Department of Veterinary Surgery, School of Veterinary Medicine and Animal Sciences, Kitasato University, Towada-shi, Aomori 0348628, Japan.

1) 茶屋ヶ坂動物病院， ${ }^{2)}$ 名古屋大学医学部付属動物実 験施設, ${ }^{3}$ 同大学院医学研究科医療技術学専攻病態 解析学分野, ${ }^{4}$ 同大学院研究科健康社会医学専攻社 会生命科学講座環境労衝衛生学教室, ${ }^{5}$ 北里大学獣医 畜産学部獣医外科学教室
}

\section{MATERIALS AND METHODS}

Nine adult Beagle dogs of both sexes with the body weight ranging from 6.6 to $9.0 \mathrm{~kg}$ (mean, $8.4 \mathrm{~kg}$ ) were used in this experiment with a cross-over design. The dogs were classified into 3 groups according to the depth of ether anesthesia ; I (middle), II (deep), and III (light) groups. They were used all the three experiments above at a 7day interval. The same dog received the different depth of ether anesthesia in the order of I - II - III (3 dogs), II - III - I (3 dogs), and III - I - II (3 dogs), respectively. All the experiments were performed under the guidelines for animal care of School of Medicine, Nagoya University.

Hypothermia technique: The details of our method of surface-induced deep hypothermia in the dog have been reported previously $\left.{ }^{10}, 11\right)$, and summarized in the protocol of hypothermia techniques (Fig. 1). The premedication drugs used were shown in Table 1. Anesthesia was induced with thiamylal sodium $(1.25-1.9 \mathrm{mg} / \mathrm{kg}$ body weight, iv) and the animals were intubated. Ether was inhaled with an in-circuit wick type vaporizer (D-322, Acoma, Tokyo) in a closed circuit. Pancuronium bromide at a dose of $0.04 \mathrm{mg} /$ $\mathrm{kg}$ was injected intravenously before the beginning of ether anesthesia. The dogs were then ventilated with an in-circuit respirator (AR300, Acoma) at a tidal volume of $15 \mathrm{ml}$ $/ \mathrm{kg}$ and a respiratory rate of 20 breaths per minute. The dogs were then covered with a plastic sheet, and cooled by immersing them in ice water at the end of the second ether stage (defined in the following ether anesthesia). After the esophageal temperature (ET) reached $20{ }^{\circ} \mathrm{C}$, the dogs were immediately rewarmed by immersion in circulating 


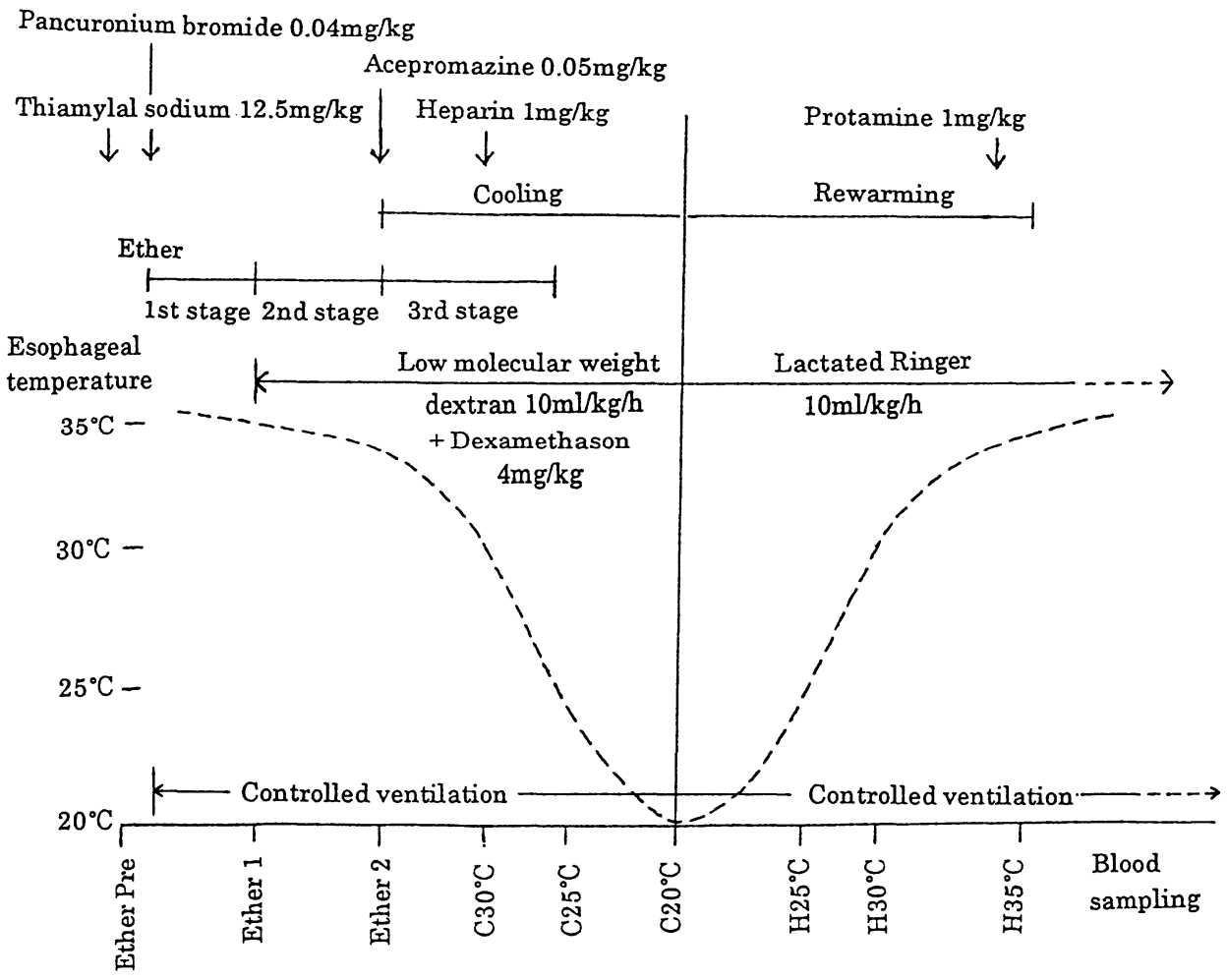

Fig. 1. Protocol of hypothermia.

(See the method)

Table 1. Premedication drugs.

\begin{tabular}{|c|c|c|c|c|}
\hline \multirow{2}{*}{ Drugs } & \multicolumn{3}{|c|}{ Before induction } & \multirow{2}{*}{$\begin{array}{l}\text { Before } \\
\text { cooling }\end{array}$} \\
\hline & $1 \mathrm{~h}$ & $30 \mathrm{~min}$ & $10 \mathrm{~min}$ & \\
\hline Hydroxyzine & 1 & 1 & & \\
\hline Acepromazine & 0.05 & 0.05 & 0.05 & 0.05 \\
\hline Atropine & 0.025 & 0.025 & & \\
\hline
\end{tabular}

$(\mathrm{mg} / \mathrm{kg})$

hot $\left(42^{\circ} \mathrm{C}\right)$ water. Ten percent low molecular weight dextran in saline solution $(10 \mathrm{ml} / \mathrm{kg}$ /hr) was infused with dexamethasone (4 mg $/ \mathrm{kg}$ ) during cooling, followed by lactated Ringer solution $(10 \mathrm{ml} / \mathrm{kg} / \mathrm{hr})$ infusion.

Ether anesthesia: The ether anesthesia was classified into three stages: the first (induction), the second (maintenance until beginning of cooling) and the third (maintenance during cooling). The depth of ether anesthesia ( I, II and III) was divided based on ether consumption. In group I (middle), vaporizer dial was set at 1.5 , and $\mathrm{I} \mathrm{ml} / \mathrm{kg}$ of ether was inhaled at the first stage, total 2 $\mathrm{m} l / \mathrm{kg}$ at the second stage and total $3 \mathrm{ml} / \mathrm{kg}$ at the third stage, respectively. In group II (deep), the dial was set at 2, and the inhaled ether volume was twice that of group I at each stage. In group III, the dial was set at 1 , and the inhaled ether volume was half that of group I at each stage. The ether was immediately stopped upon completion of the third stage and not washed until ET recovered to $30^{\circ} \mathrm{C}$ during rewarming.

Measurements : A 6 or $8 \mathrm{Fr}$ catheter for arterial pressure and a 5 Fr Swan-Gantz catheter for pulmonary arterial, pulmonary capillary wedge and central venous pressure were inserted either from the carotid artery and jugular vein, or the femoral artery and vein, respectively. These pressures as well as electrocardiogram and cardiac output (using the thermodilution method) were monitored and recorded (Life Scope 9 and Thermal Array Recorder, Nihon Kohden, Tokyo). 


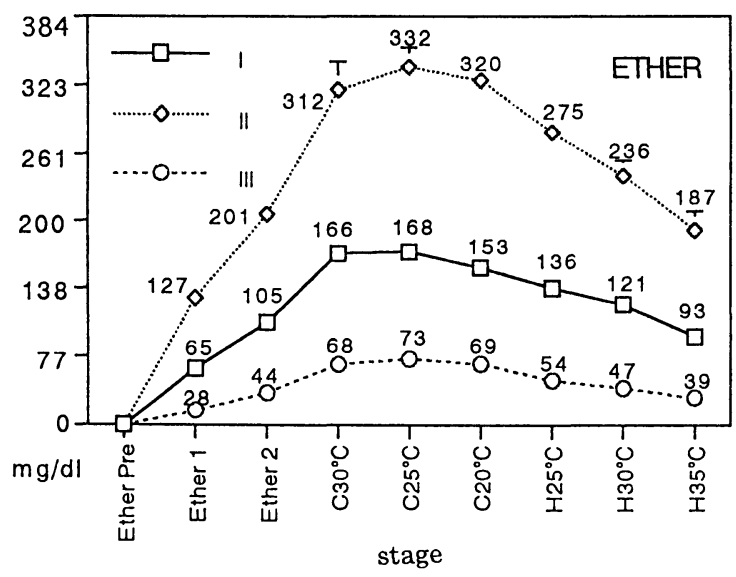

Fig. 2. Changes in blood ether concentration of three groups during hypothermia. I : Group I, II : Group II, III : Group III

Arterial blood samples for measuring blood gas and ether concentration were collected before ether anesthesia, at the end of the first and second ether stages, when ET was $30{ }^{\circ} \mathrm{C}, 25^{\circ} \mathrm{C}$ and $20^{\circ} \mathrm{C}$ during cooling, and when ET was $25^{\circ} \mathrm{C}, 30^{\circ} \mathrm{C}$, and $35^{\circ} \mathrm{C}$ during rewarming (Fig. 1 ).

Blood gases were measured at $37^{\circ} \mathrm{C}$ with an acid-base auto-analyzer (ABL30, Radiometer, Tokyo) without temperature correction. ET and rectal temperature were monitored with a telethermometer (Finer CTM 303, Terumo, Tokyo). Urine volume was monitored as an index of peripheral circulation with a balloon urethral catheter inserted into the bladder.

The blood ether concentration was determined by the n-Hexane extraction method, using a gas chromatography (GC) (GC-15A, Shimazu, Tokyo) equipped with a flame ionization detector (FID). Standard ether blood samples were prepared by adding 1, 2, 3,4 , or $5 \mu l$ ether to $1 \mathrm{ml}$ arterial blood in a $2-\mathrm{m} l$ vacuum sampling tube. These standard samples and blood samples collected from the experimental dogs were then mixed with
$1 \mathrm{~m} l \mathrm{n}$-Hexane, shaken vigorously for $15 \mathrm{~min}$ utes, and centrifuged at $3500 \mathrm{rpm}$ for $10 \mathrm{~min}$ utes. An ether-gauging curve was derived from each peak area for each $1 \mu l$ of $n$ Hexane fraction measured by GC. The conditions for GC were as follows. He was used as carrier gas at a flow rate of $40 \mathrm{ml} / \mathrm{min}$. Detector temperature was at $200{ }^{\circ} \mathrm{C}$. The column used was CBP-1 (0.32 mm inner diameter and $30 \mathrm{~m}$ in length) with analysis temperature at $40^{\circ} \mathrm{C}$.

Statistical analysis : All the values were presented as mean \pm SEM (standard error of the mean). Statistical differences among groups were analyzed by one-way analysis of variance (ANOVA) followed by TukeyKramer multiple comparison method. Differences were considered statistically significant at $p<0.05\left(^{*}\right)$ and $p<0.01\left(^{* *}\right)$.

\section{RESULTS}

Survival rate : In 3 dogs receiving the I II-III experiments in turn, all died in experiment II due to ventricular fibrillation (Vf) or standstill. Therefore, experiment III was not done in these dogs. In 3 dogs receiving the II-III- I experiments in turn, all were alive. In 3 dogs receiving the III- I - II experiments in turn, all died in experiment II due to Vf or standstill. As a result, the number of the dogs survived were 9 of 9 dogs in group I (100\%), 3 of 9 dogs in group II $(33.3 \%)$, and 6 of 6 dogs in group III (100 $\%)$, respectively.

Incidence of arrhythmia : Table 2 showed the incidence of arrhythmia during each experiment. In group II, 6 dogs died due to cardiac arrest with Vf or standstill after remarkable bradycardia (ventricular rhythm) during cooling. Serious ventricular 
Table 2. Incidence of arrhythmia of each group.

\begin{tabular}{cccccc}
\hline Group & (n) & $\begin{array}{c}\text { Cardiac arrest by } \\
\text { Vf or Standstill }\end{array}$ & $\begin{array}{c}\text { Serious } \\
\text { VT }\end{array}$ & $\begin{array}{c}\text { Single } \\
\text { VPC }\end{array}$ & $\begin{array}{c}\text { No } \\
\text { VPC }\end{array}$ \\
\hline I & 9 & & & $5 / 9(55.6 \%)$ & $4 / 9(44.4 \%)$ \\
II & 9 & $6 / 9(66.7 \%)$ & & $2 / 9(22.2 \%)$ & $1 / 9(11.1 \%)$ \\
III & 6 & & $3 / 6(50 \%)$ & $1 / 6(16.7 \%)$ & $2 / 6(33.3 \%)$ \\
\hline
\end{tabular}

Vf : ventricular fibrillation, VT : ventricular tachycardia, VPC : ventricular premature contraction

tachycardia (VT) occurred frequently in 3 of 6 dogs in group III. Single ventricular premature contraction (VPC) occurred in 5 of 9 dogs in group $\mathrm{I}$, in 2 of 9 dogs in group II, and 1 of 6 dogs in group III. VPC was not recorded 4 of 9 dogs in group I, 1 of 9 dogs in group II, and 2 of 6 dogs in group III, respectively.

Blood ether concentration : Blood ether concentrations of dogs in groups I, II and III were proportional to inhaled ether volumes (Fig. 2). In all groups, blood ether concentrations increased according to the increased inhaled volume and reached the peak at 25 ${ }^{\circ} \mathrm{C}$ of ET during cooling, because ether inhalation was stopped upon completion of the third stage at ET $30^{\circ} \mathrm{C}$ to $25^{\circ} \mathrm{C}$. The blood ether concentration of the dog in group I was $65 \mathrm{mg} / \mathrm{d} l$ at the end of the first ether stage, $105 \mathrm{mg} / \mathrm{d} l$ at the end of the second ether stage, $166 \mathrm{mg} / \mathrm{d} l$ at $\mathrm{ET}$ of $30^{\circ} \mathrm{C}, 168 \mathrm{mg}$ $/ \mathrm{d} l$ at ET of $25^{\circ} \mathrm{C}$, and $153 \mathrm{mg} / \mathrm{d} l$ at ET of $20{ }^{\circ} \mathrm{C}$ during cooling, respectively.

Hemodynamic findings :

Heart rate (HR)

HR of all groups increased rapidly after induction of ether anesthesia. HR of groups I and III decreased slowly during cooling, and recovered rapidly during rewarming. In contrast, HR of group II decreased rapidly during cooling and increased slowly during rewarming. The differences in HR between group I or III and group II were statistically significant during cooling and

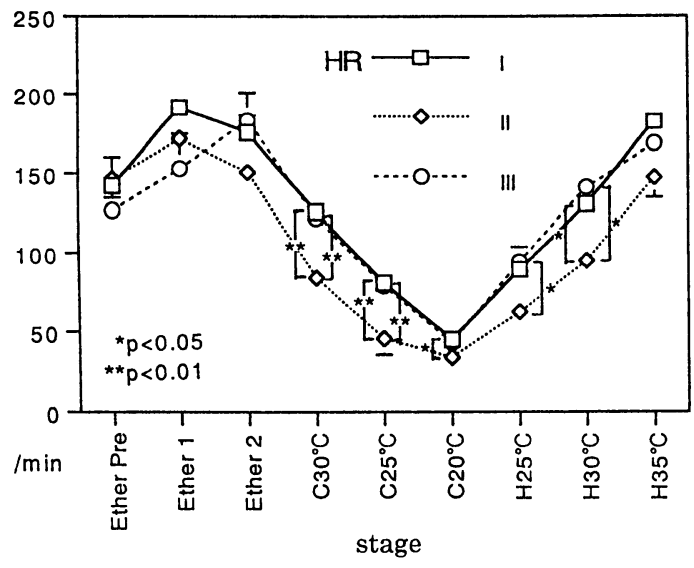

Fig. 3. Changes in heart rate (HR) of three groups during hypothermia.

I : Group I, II : Group II, III : Group III

rewarming ( $p<0.01$ or $p<0.05$ ) (Fig. 3 ).

Cardiac output (CO)

CO levels increased after induction of ether anesthesia, then decreased during cooling, and re-increased during rewarming with the highest value in group I and the lowest in group II. The difference in $\mathrm{CO}$ between group I and group II was statistically significant at $30{ }^{\circ} \mathrm{C}$ and $25^{\circ} \mathrm{C}$ during cooling $(p<0.05)$ (Fig. 4$)$.

\section{Aortic mean pressure (AOMP)}

AOMP in group II decreased remarkably after induction of ether anesthesia, during cooling and rewarming. AOMP of group I showed slight fluctuation and was maintained higher levels throughout. In contrast, AOMP in group III showed a rapid decrease during cooling but a rapid increase after the beginning of rewarming. The difference in AOMP between group I or III and group 


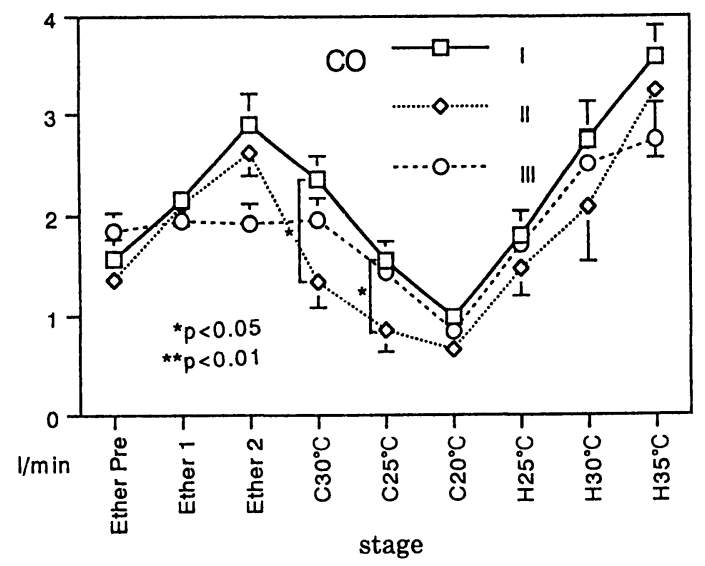

Fig. 4. Changes in cardiac output (CO) of three groups during hypothermia.

I : Group I, II : Group II, III : Group III

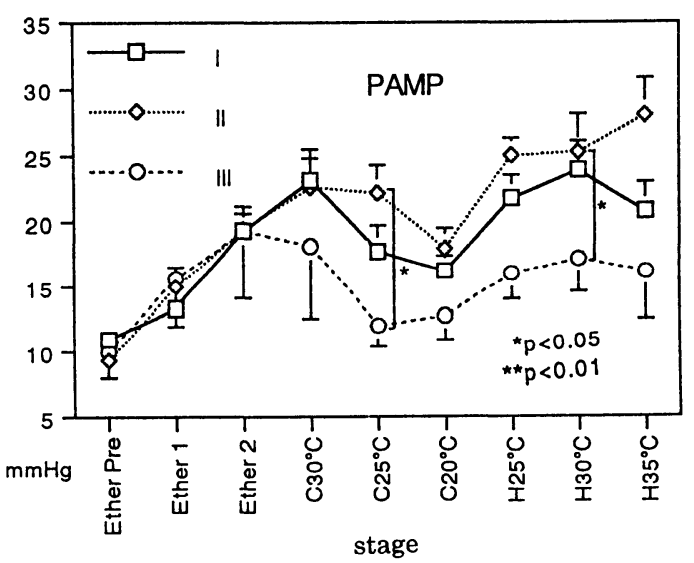

Fig. 6. Changes in pulmonary artery mean pressure (PAMP) of three groups during hypothermia.

I : Group I, II : Group II, III : Group III

II was statistically significant during cooling and rewarming $(p<0.01$ or $p<0.05)$. At ET of $20^{\circ} \mathrm{C}$, AOMP in group I was significantly higher than those in group II and III $(p<0.01)$ (Fig. 5$)$.

\section{Pulmonary arterial mean pressure (PAMP)}

PAMP increased after ether anesthesia, then decreased during cooling and reincreased after rewarming with the highest value in group II and the lowest in group III. However, the difference in PAMP between groups was not statistically significant, except for those between group II and

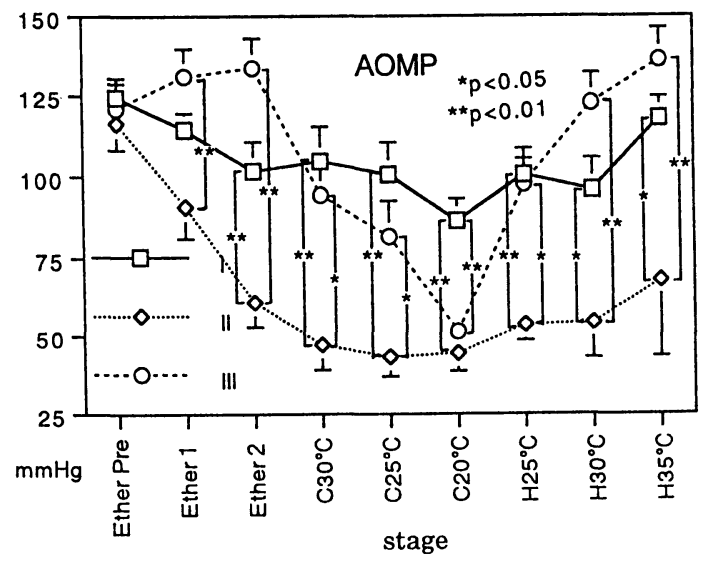

Fig. 5. Changes in aortic mean pressure (AOMP) of three groups during hypothermia.

I : Group I, II : Group II, III : Group III

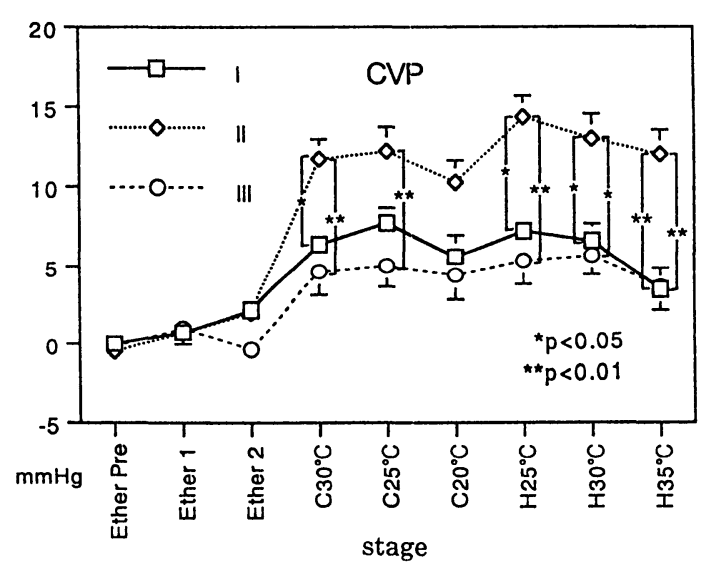

Fig. 7. Changes in central venous pressure (CVP) of three groups during hypothermia.

I : Group I, II : Group II, III : Group III

III group at ETof $25^{\circ} \mathrm{C}$ during cooling and at $30^{\circ} \mathrm{C}$ during rewarming $(p<0.05)$ (Fig. 6$)$.

Central venous pressure (CVP)

CVP increased during hypothermia (from ET of $30^{\circ} \mathrm{C}$ during cooling to $35^{\circ} \mathrm{C}$ during rewarming), with the highest value in group II and the lowest in group III. The differences in CVP between group II and groups I or III were statistically significant except at ET of $20^{\circ} \mathrm{C}(p<0.01$ or $p<0.05)$ (Fig. 7$)$.

Pulmonary capillary wedge pressure (PCWP)

Changes in PCWP during hypothermia was similar to those of CVP, except at ET of 


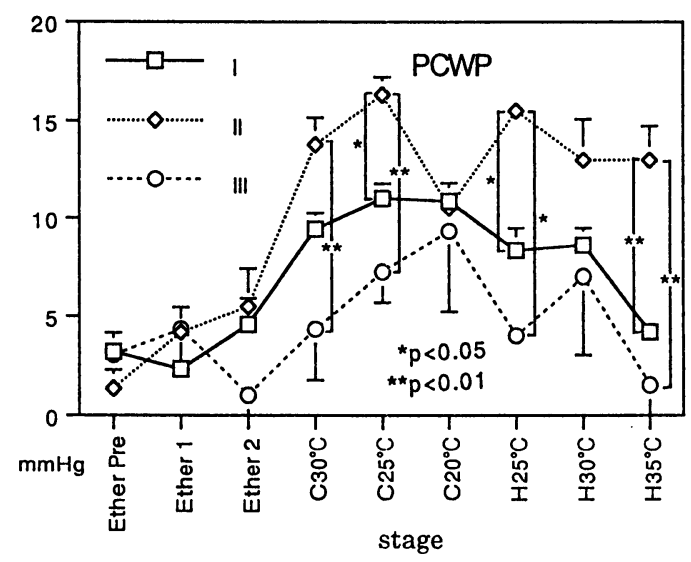

Fig. 8 Changes in pulmonary capillary wedge pressure (PCWP) of three groups during hypothermia.

I : Group I, II : Group II, III : Group III

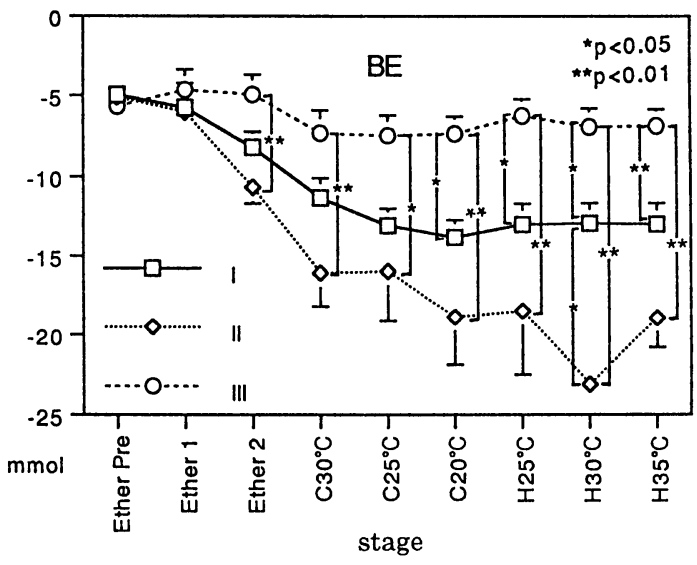

Fig.10. Changes in blood BE of three groups during hypothermia.

I : Group I, II : Group II, III : Group III

$20^{\circ} \mathrm{C}$, and PCWP of group II was the highest and that of group III was lowest. The differences in PCWP between group II and group I or III group were statistically significant ( $p<0.01$ or $p<0.05$ ) (Fig. 8 ).

\section{Blood gas findings :}

Blood pH and base excess (BE)

During hypothermia (from the beginning of cooling to $\mathrm{E} \mathrm{T}$ at $35^{\circ} \mathrm{C}$ during rewarming), $\mathrm{pH}$ and $\mathrm{BE}$ declined in proportion to the depth of ether anesthesia. The differences in $\mathrm{pH}$ or $\mathrm{BE}$ between groups were statistically significant $(p<0.01$ or $p<0.05$ ) (Fig. 9 and 10 ).

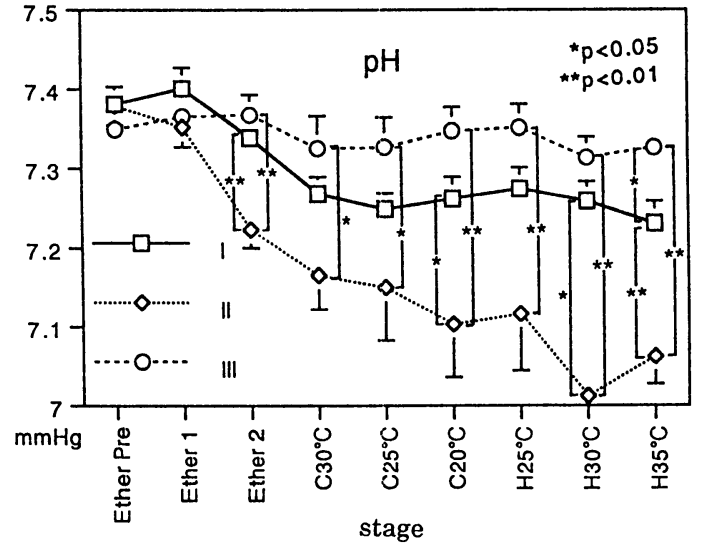

Fig. 9. Changes in blood $\mathrm{pH}$ of three groups during hypothermia.

I : Group I, II : Group II, III : Group III

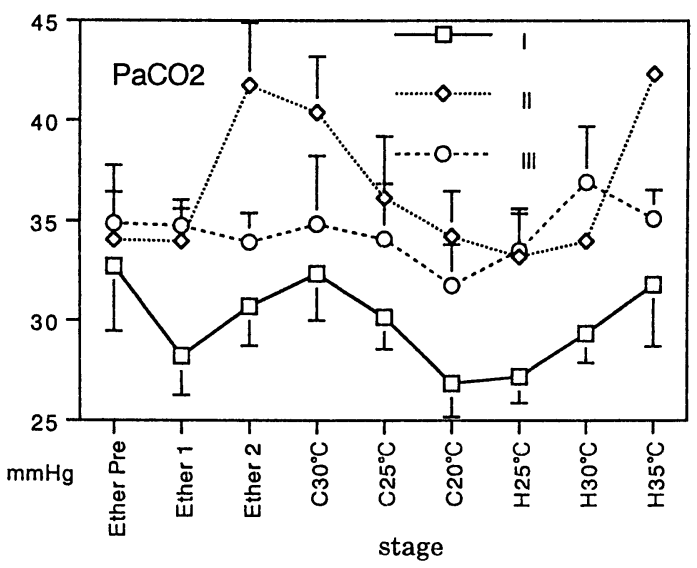

Fig.11. Changes in $\mathrm{PaCO} 2$ of three groups during hypothermia.

I : Group I, II : Group II, III : Group III

\section{$\mathrm{PaCO} 2$}

$\mathrm{PaCO} 2$ of all groups showed little fluctuation because ventilation was controlled using a respirator during the experiment (Fig. 11).

\section{$\mathrm{PaO} 2$}

$\mathrm{PaO} 2$ decreased after the beginning of anesthesia, but during hypothermia, $\mathrm{PaO} 2$ increased in proportion to the decrease in ET and decreased again during rewarming, because $\mathrm{O} 2$ consumption decreased during hypothermia (Fig. 12).

Urine volume : 


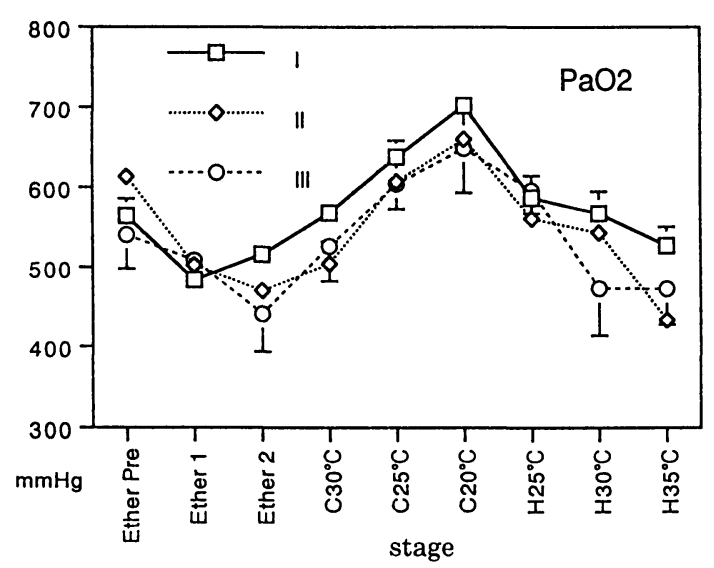

Fig.12. Changes in $\mathrm{PaO} 2$ of three groups during hypothermia.

I : Group I, II : Group II, III : Group III

Total urine excretion during hypothermia was well maintained in groups I and III, whereas it was low in group II. The differences between groups I and III and group II were statistically significant $(~ p<0.01$ and $p<0.05$ ) (Fig. 13).

\section{DISCUSSION}

\section{Arrhythmia frequency :}

During hypothermia, attacks of $\mathrm{Vf}$ were the most serious danger in the cooling period, especially bellow $28{ }^{\circ} \mathrm{C}$ of $\mathrm{ET}^{5,}{ }^{21,}{ }^{22)}$. Therefore, deep ether anesthesia was hazily preferred to light ether anesthesia for avoiding the attacks of Vf. In this experiment, however, 6 of 9 dogs died of severe arrhythmia (Vf or ventricular standstill) in the deep ether anesthesia (group II ), and serious VT occurred in 3 of 6 dogs of the light ether anesthesia (group III). In contrast, no VPC occurred in 4 of 9 dogs and sporadic VPC in the remaining 5 dogs in middle ether anesthesia (group I ). Accordingly, it appeared that middle ether anesthesia was the safest for surface-induced hypothermia in the dog.

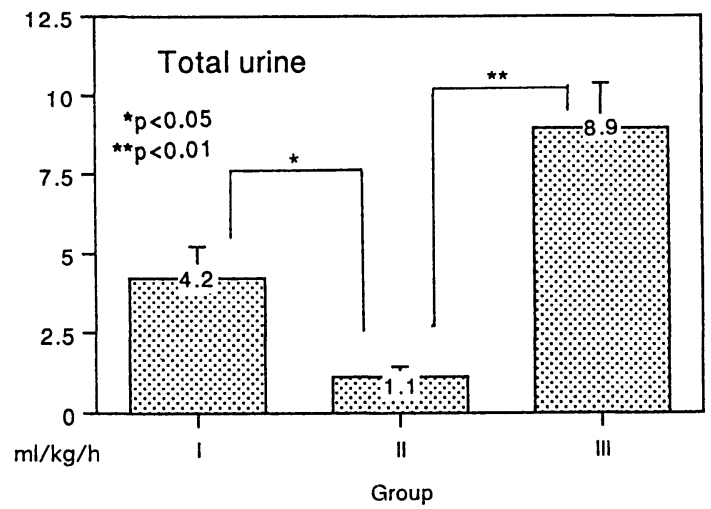

Fig.13. Total urine volume of three groups during hypothermia.

According to Sano ${ }^{21)}$, the frequency of arrhythmia in deep ether anesthesia was lower than that in neuroleptanalgesia or in thiopental sodium anesthesia. However, Hosoi et al. ${ }^{7)}$ reported the early appearance of arrhythmia in the complication group against no arrhythmia in the no complication group in human clinical cases using simple deep hypothermia with deep ether anesthesia. It was suggested that their complication group corresponded to group II or III of our experiment.

\section{Hemodynamics during hypothermia :}

According to Wakusawa et al. ${ }^{16,22)}$, low blood pressure and bradycardia were important factors for simple deep hypothermia, contributing to hypoxemia of tissue and brain injury after hypothermia.

In this experiment, during hypothermia (from ET of $30^{\circ} \mathrm{C}$ of the cooling period to 30 ${ }^{\circ} \mathrm{C}$ of the rewarming period), hemodynamic findings of groups I and III were significantly better than those in group II, especially in HR, CO and AOMP. Although AOMP was depressed in the order of groups III $>$ I $>$ II before ET at $30{ }^{\circ} \mathrm{C}$ during cooling, AOMP in group III drastically decreased when ET was lower than $30{ }^{\circ} \mathrm{C}$. During 
hypothermia under ET of $30{ }^{\circ} \mathrm{C}$, the hemodynamics seemed the most unstable in this group. AOMP of group I was significantly higher than that of groups II and III at ET of $20^{\circ} \mathrm{C}(p<0.01)$. From these results, it seemed that the hemodynamics of middle ether anesthesia was better than that of light and deep ether anesthesia during hypothermia.

Urine volume :

Urine volume is usually a good indicator of the peripheral blood circulation under normal temperature. In this experiment, total urine volume during the procedure was greater in the order of groups III $>$ I $>$ II and was in proportion to the depth of ether anesthesia during hypothermia. The differences between group II and group III or I were statistically significant $(p<0.01$ and $p<0.05)$. AOMP, a good indicator of the central blood circulation, was better in group I than in group III during severe hypothermia under ET of $30^{\circ} \mathrm{C}$. However, the urine volume of all groups markedly decreased during severe hypothermia. Therefore, urine volume mainly reflected the hemodynamics before cooling and after 30 ${ }^{\circ} \mathrm{C}$ of rewarming, but did not in hypothermia under ET of $30^{\circ} \mathrm{C}$.

\section{Blood gas :}

Acidosis was reported in hypothermia, and was thought to be a common sign of this condition $^{6,}{ }^{6,22)}$. In this experiment, it was also an important sign of the depth of ether anesthesia. Blood $\mathrm{pH}$ of the three groups showed no fluctuations until the end of the first stage of ether anesthesia. However, the deep ether anesthesia group showed a tendency to decrease to the end of the second stage of ether anesthesia (about pH 7.23). During hypothermia (from ET at $30^{\circ} \mathrm{C}$ during cooling to $35^{\circ} \mathrm{C}$ during rewarming), blood $\mathrm{pH}$ of light ether anesthesia was about 7.35 and was never below $\mathrm{pH} 7.30$. Blood $\mathrm{pH}$ of the middle ether anesthesia group was about 7.25 , not lower than 7.20. In the deep ether anesthesia group, blood $\mathrm{pH}$ lowered to about 7.10 and was significantly lower than those in the light or middle groups $(p<0.01$ or $p<0.05$ ).

Blood BE showed the similar change as that of blood $\mathrm{pH}$. Although blood $\mathrm{BE}$ showed no difference among the three groups at the end of the first stage of ether anesthesia, blood $\mathrm{BE}$ of the deep ether group dropped significantly to about - 10 compared to the value of -4.9 of the light ether group at the end of the second stage of ether anesthesia. During hypothermia, BE of the light ether group was about -7 and was never below -10 . Blood $\mathrm{BE}$ of the middle ether group was about -12 and was never below -15 . In the deep ether group, BE dropped to about -18 and was significantly lower than those of other two groups $(p<0.01$ or $p<0.05)$.

As an indicator of the depth of ether anesthesia, Guedel's classification has originally been used $^{3)}$. During hypothermia, however, it is difficult to determine the depth of ether anesthesia by observing the pupil size of the eye, respiratory manner and nerve reflexes because the dog was covered with a vinyl sheet and immersed in ice water. This experiment suggested that blood $\mathrm{pH}$ and $\mathrm{BE}$ were especially reliable indicators of ether anesthesia, as arrhythmia and AOMP for the hemodynamics during hypothermia.

Blood ether concentration :

The mean blood ether concentration of the middle ether anesthesia group at ET of 20 ${ }^{\circ} \mathrm{C}$ was $153 \mathrm{mg} / \mathrm{d} l$. Miyazaki et al. ${ }^{17)}$ reported 
the value at ET of $20^{\circ} \mathrm{C}$ in human hypothermia as $285.7 \mathrm{mg} / \mathrm{d} l$, which was near to that of group II in this experiment. The value of $180 \mathrm{mg} / \mathrm{d} l$ reported by Wakusawa et $\mathrm{al}^{22}{ }^{22}$, was near to that of group I in this experiment. Moreover, this value in the dog reported by Hosoi et al. ${ }^{6}{ }^{7)}$ was $200-250 \mathrm{mg} / \mathrm{d}$

$l$. Because these values in blood ether concentration were measured by old complex procedures, the difference of these values was thought to be due to the measurement technique used.

According to Coleman's study ${ }^{2)}$ using new methods, the blood ether concentration of plane I in surgical stage II was $80-110 \mathrm{mg}$ $/ \mathrm{d} l$, and that in stage III was $140-180 \mathrm{mg} / \mathrm{d} l$ at room temperature. In surface-induced hypothermia, the depth of ether anesthesia during cooling is the most important for prevention of the cold stress, especially at the beginning of cooling. The blood ether concentration $(105 \mathrm{mg} / \mathrm{d} l)$ of our group I at the beginning of cooling coincided with that $(80-110 \mathrm{mg} / \mathrm{d} l)$ in plane I of surgical stage III of Coleman's study, and the value of 153 $\mathrm{mg} / \mathrm{d} l$ of group I at ET of $20^{\circ} \mathrm{C}$ coincided with that $(140-180 \mathrm{mg} / \mathrm{d} l)$ in surgical stage IV of his study at room temperature.

\section{CONCLUSION}

1) Concerning hemodynamics during hypothermia, ether anesthesia in groups I and III was significantly better than that in group II. Especially, AOMP of group I was significantly superior to that of group III at ET of $20^{\circ} \mathrm{C}$. The incidence of severe arrhythmia was higher in groups II and III . Therefore, ether anesthesia used in group I was demonstrated to be the best for surfaceinduced hypothermia in the dog.
2) Blood $\mathrm{pH}$ and $\mathrm{BE}$ as well as arrhythmia and AOMP were excellent indicators for evaluating the depth of ether anesthesia.

3) The optimal mean blood ether concentration determined during hypothermia in the dog was $153 \mathrm{mg} / \mathrm{d} l$ at ET of $20^{\circ} \mathrm{C}$.

\section{REFERENCES}

1) Baba, K. (1977): Deep hypothermia by surface cooling with neuroleptanesthesia. J. Jpn. Assoc. Thorac. Surg. $25: 1241^{-}$ 1254 (in Japanese with English summary).

2) Coleman, A. J. (1984): Diethyl ether. In : A Practice of Anaesthesia, 5 th ed. (Churchill-Davidson, H. C. ed.), pp. 181 189. Lloyd-Luke Ltd., London.

3) Guedel, A.E. (1951) : Inhalation Anesthesia, 2 nd ed., The Macmillan Co., New York.

4) Haneda, K., Sands, M.P., Thomas, R., Merrick, S. H., Hessel II , E. A. and Dillard, D. H. (1982) : Circulatory dynamics during surface-induced hypothermia under halothane-ether azeotrope anesthesia. Ann. Thorac. Surg. 33 : 258 $-266$.

5) Holmberg, D. L. (1993) : Hypothermia. In : Textbook of Small Animal Surgery, 2nd ed., vol. 1 (Slatter, D. ed.), pp. 921 -922. W.B. Saunders Co., Philadelphia.

6) Hosoi, Y. (1967) : Experimental and clinical study on ether anesthesia: Relation between EEG and physiological parameters. Jpn. J. Anesth. $16: 699-720$ (in Japanese with English summary).

7) Hosoi, Y., Okamura, H., Nakamura, J., Sagara, T., Matsuoka, A., Sezaki, T., Yamashita, J., Kobayashi, H., Endo, T., Katsuta, S., Kabe, T. and Saito, M. (1973) 
: Anesthetic management of surface induced profound hypothermia for openheart surgery, especially, management of cooling process. Jpn. J. Thorac. Surg. 26: 91-99 (in Japanese with English summary).

8) Hukatsu, O., Matusima, K., Huziwara, T., Kawashima, Y., Ohkawa, Y., Akasaka, T., Takaguchi, N. and Ohara, H. (1977)

: Deep hypothermia using a great deal of morphine anesthesia. Jap. J. Clin. Anesth. 1:31-41 (in Japanese).

9) Iwamoto, I., Koga, Y., Maeda, M., Hirota, K., Shibata, K., Onizuka, T., Ishii, K., Matsuzaki, Y., Sugimoto, H., Nakajima, S. and Araki, K. (1991) : Methods of anesthesia in canine heart-lung transplants. Jpn. J. Thorac. Surg. $44: 135$ 139 (in Japanese with English summary).

10) Kanemoto, I., Noguti, H., Chimura, S., Simizu, Y., Kobayasi, M. and Okuzawa, A. (1985): Hypothermia in the dog-I, Experimental results on ether anesthesia. Jpn. J. Vet. Anesth. Surg. $16: 27-34$ (in Japanese with English summary).

11) Kanemoto, I., Shibata, S., Noguti, H., Chimura, S., Shimizu, Y. and Kobayasi, M. (1987) : Hypothermia in the dog-II, The effect of controlled ventilation on cardiac resuscitation. Jpn. J. Vet. Anesth. Surg. 18:11-17 (in Japanese with English summary).

12) Kanemoto, I., Shibata, S., Noguti, H., Chimura, S., Kobayashi, M. and Shimizu, Y. (1990) : Successful mitral valvuloplasty for mitral regurgitation in a dog. Jpn. J. Vet. Sci. $52: 411-414$.

13) Manohar, M. and Tyagi, R. P. S. (1972) : Surface-induced deep hypothermia and prolonged circulatory stasis in dogs. J. Am. Vet. Med. Assoc. $161: 371$ $-377$.

14) Matsumoto, M., Tokaji, A., Kurasako, T., Odaka, Y., Mutoh, J., Takatori, M., Morimoto, N. and Tada, K. (1985) : Anesthesia for pediatric cardiac surgery with fentanyl and PGE1 under hypothermia - Fentanyl dosing schedule. J. Jpn. Soc. Hypothermia 5:19-28 (in Japanese with English summary).

15) Meyer, R. E., Gleed, R. D. and Harvey, H. J. (1984) : Isoflurane anesthesia as an adjunct to hypothermia for surgery in a dog. J. Am. Vet. Med. Assoc. 184 : $1387-1389$

16) Miura, M., Okada, K., Takada, Y., Isida, M. and Wakusawa, R. (1986) : Practical application of dobutamine on simple hypothermia. Jpn. J. Clin. Anesth. 10 : 683-685 (in Japanese).

17) Miyazaki, M., Yoda, K., Tanaka, Y., Tsukawaki, Y. and Oguli, K. (1980): A study of profound hypothermia by surface cooling. Can. Anesth. Soc. J. 27 : $370-380$.

18) Mohri, H., Hessel II, E. A., Nelson, R. J., Matano, I., Anderson, H. N., Dillard, D. H. and Merendino, K.A. (1966): Use of rheomacrodex and hyperventilation in prolonged circulatory arrest under deep hypothermia induced by surface cooling-Method for open heart surgery in infants. Am. J. Surg. 112 : 241-250.

19) Mohri, H., Dillard, D. H. and Merendino, K. A. (1972) : Hypothermia : Halothane anesthesia and the safe period of total circulatory arrest. Surgery $72: 345-351$.

20) Moon, P. F. and Ilkiw, J.E. (1993) : Sur face-induced hypothermia in dogs : 19 cases $(1987$ - 1989). J. Am. Vet. Med. Assoc. $202: 437-444$. 
21) Sano, A. (1980): Study on mechanism of ventricular fibrillation in deep hypothermia. J. Jpn. Assoc. Thorac. Surg. 28 : 35-47 (in Japanese with English summary).

22) Wakusawa, R. and Okada, K. (1989): Hypothermia. In : Anesthesia (New Encyclopedia of Surgical Science, vol. 3) (Kimoto, S. \& Wada, T. eds.), pp. 149 - 166. Nakayama Shoten Co., Tokyo (in Japanese).

23) Weirich, W. E. (1975) : Surface-induced deep hypothermia. In : Current Techniques in Small Animal Surgery I (Bojrab, M. J. ed.), pp. 322-325. Lea \& Febiger, Philadelphia.

\begin{abstract}
和文要約
エーテル麻酔深度が低体温麻酔法の血行動態と 血液ガスに及ぼす影響をビーグル成犬を用いて調 べた。エーテル麻酔深度により 3 群に分けた; す なわち I (中麻酔) 群, II (深麻酔) 群, III (浅 麻酔）群である。重篤な不整脈が II 群と正群で認 められ，II群の 6 頭（66.7\%）は心室細動之心室 停止で死亡した。低体温麻酔中の血行動態は, I 群と III群が II 群よりも有意に良好であった。また, I 群の平均動脈圧 (AOMP) は吕群よりあ良好 であり, 特に食道温 $20{ }^{\circ} \mathrm{C}$ では有意な差が認めら

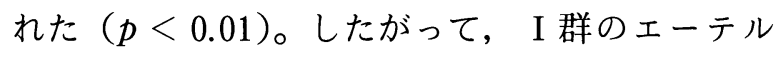
麻酔深度が最も良い成績を示した。また，I群の 血中エーテル濃度は, 食道温 $20^{\circ} \mathrm{C}$ で $153 \mathrm{mg} / \mathrm{d} l$ であった。さらに, 低体温麻酔中の血液 $\mathrm{pH}$ と $\mathrm{BE}$ は血中ェーテル濃度と良い相関を示したため, 血液 $\mathrm{pH}$ と $\mathrm{BE}$ は不整脈と $\mathrm{AOMP}$ ともにエー テル麻酔深度の良い指標となることが示唆された。
\end{abstract}

